\title{
$1: 26483139-26486599$
}

National Cancer Institute

\section{Source}

National Cancer Institute. 1: 26483139-26486599. NCI Thesaurus. Code C42476.

Physical location of HMGN2_Gene 